\title{
The Influence of School Leadership and Work Culture on Teacher Professionalism
}

\author{
Nelianti $^{1 *}$, Happy Fitria ${ }^{2}$, Yenny Puspita ${ }^{2}$ \\ ${ }^{I}$ SMA Negeri 1 Runjung Agung, OKU Selatan \\ ${ }^{2}$ Universitas PGRI Palembang \\ *Corresponding author. E-mail: antinely2602@gmail.com
}

\begin{abstract}
This article aimed to find the influence of principal leadership and work culture on teacher professionalism. This research was conducted in Senior High School, Muaradua District, Ogan Komering Ulu East Regency. The researcher used quantitative research. While the research method used partial and simultaneous correlation. The sample in the study was the principal and teachers of SMA Negeri 1 Muaradua, SMA Negeri 2 Muaradua and SMA Muhammadiyah Muaradua at Muaradua district, totaling 75 people. Data collection technique used a questionnaire. The results showed that. The fastest significant influence of principal leadership on the professionalism of high school teachers in Muaradua District. There was a significant influence of Work Culture on teacher professionalism. There was a significant influence jointly between principal leadership and work culture on teacher professionalism. There was also a great influence of principal leadership and work culture on the professionalism of high school teachers in Muaradua District, OKU Selatan Regency together by $80 \%$ and the rest is influenced by other factors not examined in this study.
\end{abstract}

Keywords: Principal Leadership, Work Culture, Teacher Professionalism

\section{INTRODUCTION}

National education standards aim to ensure the quality of national education in the context of educating the nation's life and shaping the character and dignity of the nation's civilization. In order to achieve these objectives, government regulation number 19 of 2005 concerning national education standards (PP No. 19 of 2005), establishes eight standards that must be met in implementing education.[1] The eight standards in question include: content standards, process standards, graduate competency standards, education and educational staff standards, facilities and infrastructure standards, management standards, financing standards and educational assessment standards.[2] This means that in order to achieve the desired quality of graduates, the quality of teaching staff (teachers) and education personnel (principals, supervisors, laboratory assistants, librarians, administrative staff, messengers) must be improved.

The teacher is a resource element that is critical to the success of education in schools, because teachers are a human element that is very close to their relationship with students in daily education efforts at school. Professionalism is a job or activity carried out by someone and becomes a source activities that are carried out by a person and become a source of living income that require expertise,[3] proficiency or skills that meet certain quality standards or norms and require professional education (RI Law No. 14 of 2005 on Teachers and Lecturers). Professional teachers are teachers who are able to manage themselves in carrying out their duties

daily. The professional ability of teachers is the ability to carry out tasks, which are equipped with competence (basic skills). [3] developed five basic abilities that urriculum, (2) Mastery of the material for each subject, (3) Mastery of evaluation methods and techniques, (4) Commitment to assignments, (5) Discipline Professional ability is one of the supporting elements for teachers in realizing work performance (performance). Performance is defined as a measure of work, work implementation, work achievement, or work results.

The low quality of teachers according to [3] can be seen from the following symptoms:(1) weak mastery of the material being taught, (2) the mismatch between the fields of study studied by the teacher (3) ineffective teaching methods, (4) lack of teacher authority in front of students, (5) weak motivation and dedication to become true educators really, (6) lack of emotional maturity, independent thinking and toughness in attitudes in enough teachers so that from their personalities 
they are actually not ready to become educators, most teachers in their relationship with students only function as teachers not as educators, (7) the relatively low intellectual level of incoming teacher candidates LPTKs than those who entered university.[4]

Therefore, efforts to improve the quality/ image of the teacher, one of the components that play a role is to improve teacher professionalism which is characterized: mastering duties, roles, and competencies, having a high commitment to their profession, and adopting a learning paradigm not only in the classroom but also for themselves.[5] do continuous education all the time. The problem of leadership always gives an interesting impression, because an organization will succeed or fail partly determined by the quality of leadership. Leadership is the ability to influence, mobilize and direct actions on a person or group of people to achieve certain goals in certain situations. Leadership is one of the managerial aspects of organizational life which is a key position. Because the leadership of a leader acts as a harmonizer in the process of cooperation between people in their organization.[6] According to [7], leadership is the ability to influence a group of members to work towards goals and objectives. [7]

[8] suggests that leadership is a way for a leader to influence the behavior of his subordinates, so that they are willing to work together and work productively to achieve organizational goals. A leader who is responsible for creating a conducive and safe work environment so that people can work with enusiasm. According to [8] leadership is the ability to mobilize, motivate and influence people to be willing to take actions directed at achieving goals regarding the success made regarding the courage to make decisions about the activities carried out.[8] The head of the school as the highest leader in the school is considered successful if it can improve teacher performance through various forms of coaching activities on the ability of teachers to carry out learning in school. For that the principal must be able to carry out his / her roles and responsibilities as an education manager, education leader, education supervisor, education administrator, coaching other educational personnel and the utilization and maintenance of facilities and infrastructure. The principal is expected to be able to create a comfortable and conducive working atmosphere at school, so that every teacher can work optimally so that performance can be achieved. The leadership of the principal really determines the quality, without good leadership the quality improvement process cannot be carried out and realized [9].

The importance of school principal leadership influence is not merely a form of instruction, but rather a motivation or trigger that can inspire teachers and employees, so that their initiative and creativity develop optimally to improve their performance [10]. The reality in the leadership field of school principals still shows that their performance is not optimal,[10] this is indicated, among others, that there is still a lack of school principals to carry out supervision activities and the level of teacher satisfaction with school principal leadership is still low.

Work culture factors also affect teacher professionalism. Work culture is basically the values that become a person's habits in determining the quality of a person at work. The work culture of teachers can be seen from their sense of responsibility in carrying out their mandate, the profession they carry, their sense of moral responsibility. This attitude will be accompanied by a sense of responsibility for creating and preparing for the teaching and learning process as well as evaluation and analysis in learning activities. The work culture of teachers is certainly different from the work culture of other professions because teachers are in the service sector. The main work culture of the teacher is that a teacher is able to put himself in various situations.

A teacher is required to be able to carry out pedagogical administrative activities continuously. A teacher is also required to follow the development of educational and teaching methodologies. A teacher is required to maximize the potential for insight and time. However, in a school, of course the teacher is required to be able to give the best performance at his school. according to the competence they have. But competence alone is not enough so that teachers can give their best performance in their work.

Based on the background description, there is a tendency to weaken teacher professionalism in teaching. So that the authors are interested in conducting research on "The Influence of Principal Leadership and Work Culture on the Professionalism of High School Teachers in Muaradua District, South OKU Regency"

\section{METHODS}

This research is a quantitative research, with the Expost facto method, which is research that aims to investigate the events that have occurred and then trace back to find out the factors that caused these events [11]. This research consists of three variables in the form of two variables. independent variable and one dependent variable. The independent variable is principal leadership and work culture While the dependent variable in this study is teacher professionalism. The research was conducted at SMA Negeri 1 Muaradua, SMA Negeri 2 Muaradua and SMA Muhammadiyah Muaradua in Muaradua District OKU Selatan. The samples used were all of the 75 teachers came from the three schools. The data collection technique was used through a questionnaire, and the data that had been collected were analyzed using descriptive and inferential statistical analysis. 
Data analysis was carried out by testing the validity of research instruments on training, teaching experience, and teacher performance for each variable. An instrument is said to be valid if it is able to measure what is desired. An instrument is said to be valid if it can reveal data from the variables studied appropriately (Suharsimi, 2016). To find out whether the instrument is valid or not, if rcount> rtabel then the instrument is declared valid, on the contrary if rcount $\leq$ rtabel the instrument is declared invalid [12]. Before the analysis is carried out, the analysis requirements are first tested, which is a requirement that must be met so that the analysis can be carried out, both for predictive purposes and for hypothesis testing. There are three conditions that must be met before carrying out regression analysis, namely; 1) Normality Test, 2) Linearity Test and 3) Multicollinearity Test.

\section{RESULTS AND DISCUSSION}

1. Descriptive Statistical Analysis of Principal Leadership

\begin{tabular}{lcc}
\multicolumn{3}{c}{$\begin{array}{l}\text { Chief Leadership } \\
\text { School }\end{array}$} \\
\hline$N \quad$ Valid & 75 \\
& Missing & \\
Mean & 78.88 \\
Median & 79 \\
Std. Deviation & 5.03 \\
Minimum & 68 \\
Maximum & 89
\end{tabular}

Based on the descriptive statistical table of the principal leadership variable above, it shows that the mean value is 78.88 greater than the standard deviation value of 5.03. the median value is 79 , the highest value of the 19 statements is 89 and the lowest value is 68 .

2. Descriptive Statistical Analysis of Work Culture

\begin{tabular}{|c|c|c|}
\hline & rk Culture & \\
\hline \multirow[t]{2}{*}{$N$} & Valid & 75 \\
\hline & Missing & 0 \\
\hline Mean & & 80,85 \\
\hline Median & & 81.00 \\
\hline Std. Deviation & & 5.50 \\
\hline Minimum & & 65 \\
\hline Maximum & & 92 \\
\hline
\end{tabular}

Based on the descriptive statistical table of work culture variables above, it shows that the mean value is 80.85 greater than the standard deviation value of 5.50. The median value is 81 , the highest value of the 19 statements is 92 and the lowest value is 65 .

3. Descriptive Statistical Analysis of Teacher Professionalism

Teacher Professionalism

\begin{tabular}{lcc}
\hline$N$ & Valid & 75 \\
& Missing & 0 \\
Mean & & 81.93 \\
Median & 82 \\
Std. Deviation & 5.17 \\
Minimum & 72 \\
Maximum & 92 \\
\hline
\end{tabular}

Based on the descriptive statistical table of the teacher professionalism variables above, it shows that the mean value is 81.93 greater than the standard deviation value of 5.17. median value of 82 , the highest value of 19 statements of 92 and the lowest value of 72 .

\section{Testing Data Analysis Requirements \\ a. Normality test}

In this study, the data normality test used the Kolmogorov-Smirnov test. The test criteria were 1) if the significance value was $>0.05$ then the data were normally distributed, and 2) if the significance value was $<0.05$, then the data were not normally distributed. The results of the analysis used the SPPS application program version 20 . The results of the analysis of the normality test in this study can be seen in the following table.

\begin{tabular}{|c|c|c|c|c|}
\hline & \multicolumn{4}{|c|}{ Kolmogorov-Smirnova } \\
\hline & Statistic & Df & & Sig. \\
\hline \multicolumn{5}{|l|}{ Leadership } \\
\hline $\begin{array}{l}\text { Head } \\
\text { School }\end{array}$ & .077 & & 75 & $.200^{*}$ \\
\hline \multirow{2}{*}{$\begin{array}{l}\text { Work Culture } \\
\text { Professionalism } \\
\text { Teacher }\end{array}$} & .095 & & 75 & .094 \\
\hline & .096 & & 75 & .082 \\
\hline
\end{tabular}

Based on Table 21 above, it is known that the significance value for the principal leadership variable (X1) is 0.200 and work culture (X2) is 0.094 . While the teacher professionalism variable (Y) obtained a significance value of 0.082 . So, the results of the calculation of the three variables show a significance value greater than 0.05 . Thus it 
can be concluded that the distribution of data on the three variables is declared normal.

In addition, the normality test is performed using the normal P-P Plot of Standardized Residual Regression. For Normal P-P Plot graph analysis, the basis for decision making is 1) if the data spreads around the diagonal line and follows the direction of the diagonal line, the regression model fulfills the normality assumption; 2) if the data spreads far from the diagonal and / or does not follow the direction of the diagonal line, the regression model does not meet the assumption of normality.

The results of the Normal P-P Plot chart can be seen in the following figure

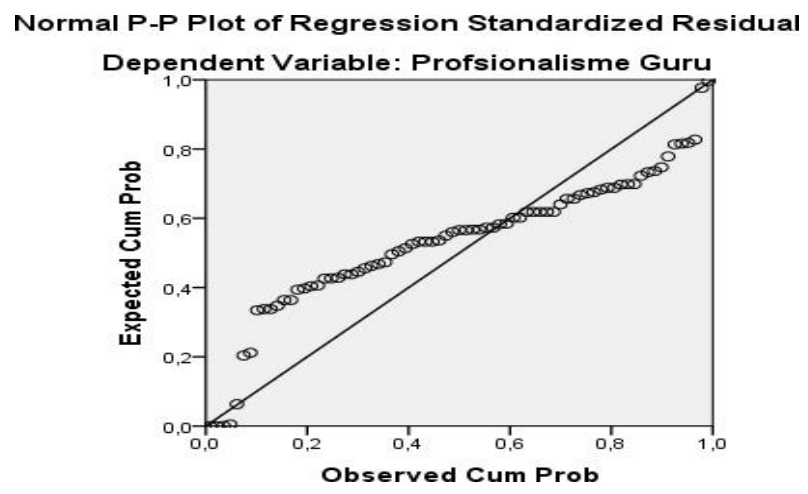

Based on the picture above, the Normal P-P Plot chart shows that the dots spread out in the direction of the diagonal line and the spread approaches around the diagonal line. Thus, it can be concluded that the regression model fulfills the assumption of normality.

\section{a. Linearity Test}

In this study, the linearity test used the Test for Linearity with a significance level. The test criteria, two variables are said to have a linear relationship if the significance value at linearity is less than 0.05 . Or if significance at Deviation for Linearity>0.05. So the two variables are linearly related. The variables tested for linearity are the principal's leadership ((X1) with teacher professionalism (Y) and work culture (X2) with teacher professionalism (Y). The results of linearity testing using the SPSS application program version 20 can be described in The following table.

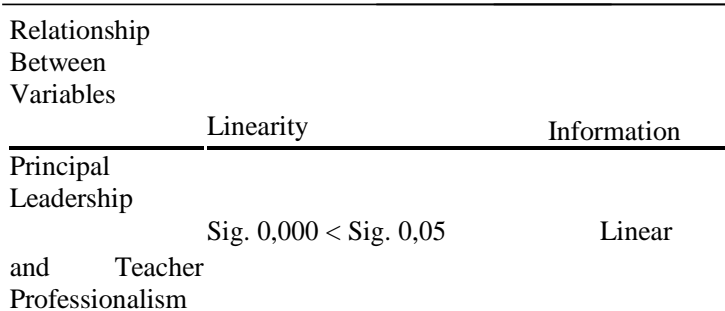

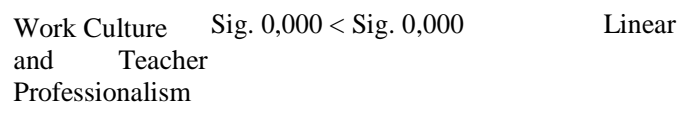

Based on the table above, it is known that the significance value in Linearity is 0,000 for the relationship between the principal's leadership variable and teacher professionalism. Then the relationship between work culture variables and teacher professionalism in Linearity is obtained a significance value of 0,000 . The two relationships between these variables in Linearity obtained a significance value of less than 0.05 . Therefore, it can be concluded that there is a linear relationship between principal leadership and teacher professionalism. Likewise, between the variables of work culture and teacher professionalism, there is a linear relationship. Thus the assumption of linearity is fulfilled for both variables.

\section{a. Multicollinearity Test}

Multicollinearity is the relationship between the independent variables contained in the regression model which has a perfect or near perfect relationship (high correlation coefficient> 0.90). In this study, the multicollinearity test was carried out by looking at the Variance Inflation Factor (VIF) and Tolerance values. The criteria are 1) if the tolerance value is $>0.10$ and the VIF value is $<10.00$, it means that there is no multicollinearity; and 2) if the tolerance value $\leq$ 0.10 and the VIF value> 10.00 , it means that there is multicollinearity. Multicollinearity testing uses the computer facilities of the SPSS application program version 20 . The results can be presented in the following table

\section{Coefficients $^{\mathrm{a}}$}

\begin{tabular}{|c|c|c|c|}
\hline \multirow[b]{2}{*}{ Model } & & \multicolumn{2}{|c|}{ Collinearity Statistics } \\
\hline & & Tolerance & $V I F$ \\
\hline \multirow{5}{*}{1} & Leadership & & \\
\hline & Headmaster & & \\
\hline & & .230 & 4.350 \\
\hline & Work Culture & & \\
\hline & & .230 & 4.350 \\
\hline $\begin{array}{l}\text { a. } \quad D \\
\text { Teacher }\end{array}$ & $\begin{array}{l}\text { pendent Variable: } \\
\text { rofessionalism }\end{array}$ & & \\
\hline
\end{tabular}

(source: Analysis of the SPSS Application Program version 20)

Based on Table 23 above, the VIF value for the variable principal leadership and work culture is VIF $=4,350$. The VIF value of the two variables is less than 10.00. Then for the torelance value of the two variables is 0.230 and the value is more than 0.10 . So it can be concluded that the regression model does not occur multicollinearity, or in other words there is no 
significant relationship between the independent variables.

Hypothesis test

Inferential statistical analysis is a multiple linear regression analysis that explains the output of the SPSS version 20 program used in testing the hypothesis. This analysis consists of multiple linear regression analysis, $\mathrm{F}$ test analysis (simultaneous) $\mathrm{t}$ test (partial) and the coefficient of determination.

\section{a. Result of Partial Hypothesis Testing ( $\mathrm{t}$ test)}

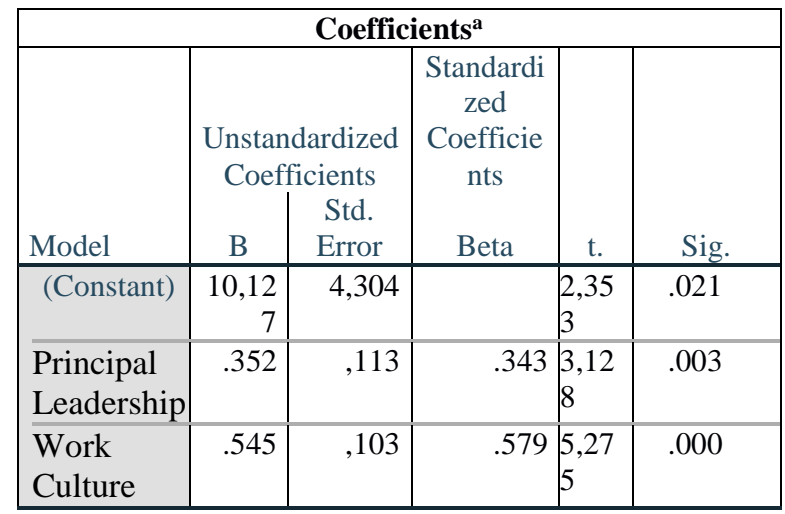

a. Dependent Variable: Work Culture

Based on the $t$ test, the value of $t$ count (13.798)> $t$ table (1.980) was obtained. Then for the significance test obtained the value of $\mathrm{Sig}=0.000<0.05$. The results of the Hypothesis 1 test can be concluded as follows:

1. Ho1 is rejected, meaning that the hypothesis which states that there is no significant effect of principal leadership on teacher professionalism is rejected.

2. Ha1 accepted, meaning that the hypothesis which states that there is a significant influence of principal leadership on teacher professionalism is accepted.

a. Multiple Linear Regression Test Results

\begin{tabular}{|c|c|c|c|c|c|}
\hline \multicolumn{6}{|c|}{ Coefficients $^{\mathrm{a}}$} \\
\hline \multirow[b]{2}{*}{ Model } & $\begin{array}{r}\text { Unstar } \\
\text { Coef }\end{array}$ & $\begin{array}{l}\text { ardized } \\
\text { cients }\end{array}$ & $\begin{array}{l}\text { Standardized } \\
\text { Coefficients }\end{array}$ & \multirow[b]{2}{*}{ t. } & \multirow[b]{2}{*}{ Sig. } \\
\hline & & $\begin{array}{l}\text { Std. } \\
\text { Error }\end{array}$ & & & \\
\hline (Constant) & $\begin{array}{r}10,12 \\
7\end{array}$ & 4,304 & & $\begin{array}{l}2,35 \\
3\end{array}$ & .021 \\
\hline $\begin{array}{l}\text { Principal } \\
\text { Leadership }\end{array}$ & .352 & ,113 & .343 & $\begin{array}{l}3,12 \\
8\end{array}$ & .003 \\
\hline $\begin{array}{l}\text { Work } \\
\text { Culture }\end{array}$ & .545 & 103 & .579 & $\begin{array}{l}5,27 \\
5\end{array}$ & .000 \\
\hline
\end{tabular}

a.Dependent Variable: Teacher Profesionalism

Based on Table 28, it is known that the constant is 10,127 , the regression coefficient for the principal leadership variable is 0.352 and the school work culture variable is 0.545 , so that the regression equation is obtained as follows

$\mathrm{Y}=10.127+0.352 \mathrm{X} 1+0.545 \mathrm{X} 2$

From the regression equation above, it can be explained as follows:

a. A constant of 10,127 means that if the principal's leadership and school work culture are zero, then the professionalism of the teacher is 10,127 .

b. The regression coefficient of the principal's leadership variable is 0.352 , that is, if the principal's leadership has increased by one

c. The regression coefficient of the school work culture variable is 0.545 , meaning that if the school organizational culture has increased by one unit, then the professionalism of the teacher will increase by 0.545 units, assuming the other independent variables are of fixed value.

c. Results of testing the hypothesis simultaneously (together)

The simultaneous test using the $\mathrm{F}$ test aims to determine the effect of the independent variables (leadership and work culture) together on the dependent variable (teacher professionalism).

\begin{tabular}{|c|c|c|c|c|c|c|}
\hline \multicolumn{7}{|c|}{ ANOVA $^{\mathrm{a}}$} \\
\hline \multicolumn{2}{|c|}{ Model } & $\begin{array}{l}\text { Sum of } \\
\text { Squares }\end{array}$ & df & $\begin{array}{l}\text { Mean } \\
\text { Square }\end{array}$ & $\mathrm{F}$ & Sig. \\
\hline \multirow[t]{3}{*}{1} & Regression & 1589,120 & 2 & 794,560 & 144.613 & $.000^{\mathrm{b}}$ \\
\hline & Residual & 395,547 & 72 & 5,494 & & \\
\hline & Total & 1984,667 & 74 & & & \\
\hline
\end{tabular}

a. Dependent Variable: Teacher Professionalism

b. Predictors: (Constant), Work Culture, Principal Leadership

Based on the F test, it was obtained that the value of Fcount (144.631)> Ftable (3.07). Then the significance test obtained the value of $\mathrm{Sig}=0.000$ $<0.05$. The results of hypothesis 3 test can be concluded as follows

1) Ho3 is rejected, meaning that the hypothesis which states that there is no significant influence together with principal leadership and work culture on teacher professionalism is rejected.

2) $\mathrm{Ha} 3$ is accepted, meaning that the hypothesis which states that there is a significant influence jointly between principal leadership and work culture on teacher professionalism is accepted.

c. Determinant Coefficient

To find out how much influence the independent variables (principal leadership and work culture) have on the dependent variable 
(teacher professionalism) simultaneously can be seen below.

Results of the Determinant Coefficient of Principal Leadership (X1) and Work Culture (X2) on Teacher Professionalism (Y)

\begin{tabular}{|l|c|r|r|r|}
\hline \multicolumn{5}{|c|}{ Model Summary } \\
\hline Model & $\mathrm{R}$ & $\begin{array}{c}\mathrm{R} \\
\text { Square }\end{array}$ & $\begin{array}{c}\text { Adjusted R } \\
\text { Square }\end{array}$ & $\begin{array}{c}\text { Std. Error of } \\
\text { the Estimate }\end{array}$ \\
\hline 1 & $.895^{\mathrm{a}}$ & .800 & .795 & 2.344 \\
\hline
\end{tabular}

a. Predictors: (Constant), Work Culture, Principal Leadership

Based on Table 30 above, it can be seen that the contribution of the principal's leadership variable and school work culture to teacher professionalism can be obtained from the $\mathrm{R}$ Square value of 0.800 . This shows that the percentage of the contribution of the influence of the principal's leadership variable and school work culture on teacher professionalism is equal to $80 \%$. Or the variation of the independent variables used in this research model is able to explain $80 \%$ of the dependent variable. While the remaining $20 \%$ is influenced by other variables not included in this research model.

Based on the results of data processing collected from 75 teachers at three SMA Muaradua District of OKU Selatan Regency, namely SMA Muhammadiyah Muaradua, SMA Negeri 1 Muaradua and SMA Negeri 2 Muardua in descriptive statistical tables and frequency distribution of variable data of principal leadership as measured by category measurement. From these results, it shows that the principal's leadership is in the quite good category. Meanwhile, the results of the data analysis show that the principal's leadership has a significant effect on teacher professionalism. Then the size of the principal's contribution to teacher professionalism has increased due to the influence of the principal's leadership.

The value obtained in this study clearly proves that the principal's leadership has a significant effect on teacher professionalism. These findings also indicate that the attitude and leadership methods of a good and correct principal will greatly influence the effectiveness of a school, especially in increasing the professionalism of teachers in the school. The results of this study are supported by previous research conducted by [13] [14] with the results which state that the principal can play a positive role in the development of teachers. commitment and responsibility of their duties. Teachers need to get strong encouragement from the principal to dare to get out of the world of their daily routine and enter into a dynamic world which is a prerequisite for a professional development of the teachers themselves in order to increase their competence to support their noble duties as a professional teacher. Then the research conducted by [15] with results describing that teacher teaching performance, teacher compensation, teacher work motivation, and principal leadership are in the high category. Principal leadership has a direct influence on teacher teaching performance and indirectly affects performance. teaching teachers Indirect influence through teacher compensation and through teacher work motivation. Meanwhile, the rest is influenced by other variables.

Also the results of research by [16] [17]by presenting the results that the leadership of the principal of SMA Negeri 4 Wira Bangsa Meulaboh and SMA Neferi 3 Meulaboh was able to improve teacher performance in each school. This is evident from the curriculum, students, facilities and infrastructure as well as student learning achievement running well according to teacher performance standards. The teacher's response and response to the leadership approach taken by the principal at SMA Negeri 4 Wira Bangsa Meulaboh and SMA Negeri 3 Meulaboh was quite good

Meanwhile, the results of research revealed by [18] [19] [20] show that there is a positive and significant effect of 1) teacher competence and principal leadership on teacher work motivation at SMK in Hulu Sungai Selatan District, South Kalimantan, either individually or collectively. 2) Teacher competence, principal leadership and teacher work motivation on the performance of vocational school teachers in Hulu Sungai Selatan District, South Kalimantan, both individually and collectively and directly and indirectly. The findings in this study strengthen the theoretical perspective that school as a system includes a number of interacting components impact on other components. In this study the variables of principal leadership and work culture jointly affect the improvement of teacher professionalism, based on the calculation of the F test and the amount of the contribution of principal leadership and work culture to teacher professionalism, meaning that the percentage of the variable contribution of principal leadership and work culture to teacher professionalism big.

The figures for the effective contribution of the independent variable to the value of the dependent variable are the results of data analysis in the field that reflect the effectiveness of the implementation of the principal's leadership and work culture as independent variables on the professionalism of high school teachers in Muaradua District, South OKU Regency. The findings of this study reveal that the principal's leadership and work culture have a significant influence on teacher professionalism.

The results of the above research are also supported by the results of research conducted by [21] [22] which shows that the principal's leadership has a significant effect on school 
effectiveness, school culture has a significant effect on school effectiveness, and teacher performance has a significant effect on school effectiveness. Principal leadership, school culture and teacher performance together have a significant effect on school effectiveness.

\section{CONCLUSION}

Based on data analysis and testing the hypothesis that the principal's leadership and work culture have an influence on teacher professionalism, it can be concluded as follows: The Effect of Principal Leadership on Teacher Professionalism. There is a significant influence of principal leadership on teacher professionalism, increasingly in SMA Muaradua District, OKU Selatan Regency. The Influence of School Work Culture on Teacher Professionalism.. There is a significant influence of work culture on teacher professionalism in SMA Muaradua District, South OKU Regency. The Influence of Principal Leadership and School Work Culture on Teacher Professionalis There is a significant influence jointly with the leadership of the principal and work culture on the professionalism of teachers in SMA Muaradua District, South OKU Regency.

\section{REFERENCES}

[1] Romlah, O. Y., \& Latief, S. (2021). Empowering the Quality of School Resources in Improving the Quality of Education. Bulletin of Science Education, 1(1), 37-41.

[2] Nugraha, D., Reftyawati, D., \& Sari, Y. A. (2020). The Effective School Strategic Plan Implementation: A Best Practice of School Improvement. Attractive: Innovative Education Journal, 2(2), 9-19.

[3] Fuad, M., Subandi, S., \& Muslan, G. (2021). Teachers' Professionalism and Parents' Motivation in Learning Aswaja at Ma Tri Bhakti At-Taqwa Raman Utara. Bulletin of Pedagogical Research, 1(1), 1-15.

[4] Arikunto, S. 2002. Prosedur Penelitian suatu Pendekatan Praktek. Rineka Cipta:Jakarta.

[5] Arlita, S. E., Ahyani, N., \& Missriani, M. (2020). Pengaruh Kompetensi Akademik dan Motivasi Guru Terhadap Kinerja Guru. Attractive: Innovative Education Journal, 2(3), 8-14.

[6] Sarni, S., \& Muslimah, M. (2021). The Commendable Leadership in Islamic Perspective. Bulletin of Pedagogical Research, 1(1), 163-173.

[7] Agus, I. (2009). Statistik Konsep Dasar dan Aplikasinya. Kencana Perdana:Jakarta

[8] Hasibuan, M. S. (2009). Manajemen Sumber Daya Manusia. Edisi revisi.

Cetakan ke-12. Jakarta: Bumi Aksara.

[9] Hasibuan, M. S. (2010). Manajemen Sumber
Daya Manusia. Jakarta: Bumi Aksara.

[10] Hasibuan, M. S. (2014). Manajemen Sumber Daya Manusia. Jakarta: Bumi Aksara

[11] Cahyono. (2012). "Analisa Pengaruh Kepemimpinan, Motivasi dan Budaya Organisasi terhadap Kinerja Dosen dan Karyawan di Universitas Pawyatan Daha Kediri”, Jurnal Ilmu Manajemen, Revitalisasi, Vol. 1, Nomor 1, Juni 2012

[12] Danim, S. (2012). Motivasi Kepemimpinan \& Efektivitas Kelompok. Jakarta: Rineka Cipta

[13] Daryanto dan Tutik Rachmawati. 2013. Penilaian Kinerja Guru dan Angka Kreditnya. Yogyakarta: Gava Media

[14] Dale. (2010). Motivasi Kepemimpinan \& Efektivitas Kelompok. Jakarta: Rineka

[15] Hadari, N., \& Kurnia, R. (2015). Kepemimpinan yang Efektif. Yogyakarta : Gajah Mada Univessity Press.

[16] Hamdani. (2017). Kompetensi Pedagogik dan Motivasi Mengajar dengan Hasil

[17] Belajar Siswa Kelas XI di MAN 2 Model Medan. Jurnal Ansiru, Vol.I, No.1.

[18] Hamali, Y. A. (2016). Pemahaman Manajemen Sumber Daya Manusia Strategi Mengelola Karyawan. Yogyakarta: CAPS (Center for Academic Publishing Service).

[19] Husna, N. (2017). "Pengaruh Disiplin Kerja Terhadap Kinerja Guru Pada SMAN 1 Canduang Kabupaten Agam”. Jurnal Ekobistek Fakultas Ekonomi, Hal. $\quad$ 286298

[20] Hidayat., \& Machalin. (2012). Kepemimpinan Kepala Sekolah. Raya grafindo Persada: Jakarta.

[21] Irwantoro, N dan Suryana, Y. (2016). Kompetensi Pedagogik. Surabaya: Genta Grup Production

[22] Kartono, (2003). Motivasi Kepemimpinan \& Efektivitas Kelompok. Jakarta: Rineka Cipta 